\title{
SISTEM INFORMASI MANAJEMEN PENDAFTARAN SKRIPSI ONLINE DENGAN FITUR DETEKSI PLAGIARISME
}

\author{
Noor Latifah ${ }^{1}$, Syafiul Muzid ${ }^{2}$ \\ ${ }^{1,2}$ Program Studi Sistem Informasi Fakultas Teknik Universitas Muria Kudus
}

\section{Article Info:}

Dikirim: 02 Juni 2021

Direvisi: 22 Juni 2021

Diterima: 29 Juni 2021

Tersedia Online: 30 Juni 2021

Penulis Korespondensi: Noor Latifah

Program Studi Sistem Informasi, Fakultas Teknik,

Universitas Muria Kudus,

Kudus, Indonesia

Email: noor.latifah@umk.ac.id

\begin{abstract}
Abstrak: Skripsi merupakan proses yang wajib dilalui oleh setiap mahasiswa untukmendapatkan pengakuan sebagai sarjana. Semakin banyak mahasiswa maka semakin banyak judul skripsi yang akan diusulkan oleh mahasiswa untuk dikerjakan. Hal ini memicu terjadinya kemiripan judul (plagiat) dari skripsi yang diusulkan oleh mahasiswa. Oleh karena itu dibutuhkan sistem informasi untuk mengelola pendaftaran usulan skripsi sampai proses sidang skripsi. Saat ini Prodi Sistem Informasi UMK telah menggunakan fasilitas deteksi plagiarisme Turnitin namun aplikasi tersebut terpisah dengan proses pengelolaan skripsi di Prodi Sistem Informasi UMK. Untuk menyelesaikan permasalahan tersebut, dikembangkan sebuah sistem informasi manajemen skripsi yang terintegrasi dengan fitur deteksi plagiarism dari judul serta konten skripsi yang diusulkan oleh mahasiswa yang bisa digunakan untuk semua program studi yang ada di UMK. Penelitian yang dilakukan ini menghasilkan aplikasi system informasi yang digunakan mengelola proses pendaftaran skripsi dan deteksi plagiarism dan publikasi jurnal ilmiah.
\end{abstract}

Kata kunci: skripsi; plagiat; deteksi plagiarisme; sistem informasi skripsi.

\begin{abstract}
Thesis is a process that must be passed by every student to get recognition as a graduate. The more students, the more thesis titles that will be proposed by students to work on. This triggers the similarity of titles (plagiarism) of the thesis proposed by students. Therefore, an information system is needed to manage the registration of thesis proposals until the thesis trial process. Currently, the UMK Information Systems Study Program has used the Turnitin plagiarism detection facility, but the application is separate from the thesis management process in the UMK Information Systems Study Program. To solve these problems, a thesis management information system was developed that is integrated with the plagiarism detection feature of the title and thesis content proposed by students that can be used for all study programs at UMK. This research has resulted in an information system application that is used to manage the thesis registration process and plagiarism detection and scientific journal publications.
\end{abstract}

Keywords: thesis; plagiarism; detection of plagiarism; thesis information system. 


\section{PENDAHULUAN}

Universitas Muria Kudus Fak.Tenik Pro Sistem Informasi pertama kali dibuka dan menerima mahasiswa adalah tahun 2002. Dengan penerimaan mahasiswa sekitar 300 mahasiswa per tahun pada 8 (delapan) tahun pertama, dan saat ini skitar 150 mahasiswa per tahun penerimaan. Sampai saat ini lulusan dari Prodi SI UMK telah mencapai sekitar 2500 lulusan sedangkan mahasiswa aktif saat ini adalah sekitar 700 mahasiswa.

Banyaknya lulusan yang sudah tersebar di masyarakat menuntut Prodi SI UMK untuk selalu meningkatkan kualitas meliputi kualitas layanan dan kualitas mahasiswa. Kualitas mahasiswa dapat dilihat dari kemampuan hardskill dan softskill. Selain itu kualitas mahasiswa juga dapat dilihat dari hasil karya mahasiswa berupa tugas akhir atau skripsi Kualitas skripsi yang baik dapat dilihat dari judul maupun kontennya.

Judul maupun konten tidak boleh memiliki kesamaan dengan penelitian yang sudah ada atau disebut dengan plagiat. Dengan banyaknya jumlah mahasiswa dan lulusan di Prodi SI UMK, plagiat atau kemiripan dari skripsi sangat mungkin terjadi. Apabila ditemukan banyak plagiarisme di institusi pendidikan maka kualitas di institusi tersebut dipertanyakan. Demi menjaga kualitas skripsi mahasiswa, Rektor UMK melalui surat keputusannya membuat aturan untuk menggunakan aplikasi pendeteksi plagiat yaitu Turnitin sebagai detektor plagiat untuk skripsi yang ada di lingkungan UMK. Aplikasi ini dikenal dapat mendeteksi kemiripan sebuah artikel yang diproses. Namun aplikasi ini bersifat stand-alone yang artinya tidak terintegrasi dengan sistem informasi yang lain. Validasi proposal penelitian bahwa proposal tugas akhir yang diusulkan oleh mahasiswa akan divalidasi oleh kelompok dosen sebagai penentu lolos atau tidaknya usulan tugas akhir tersebut [1].

Teknik deteksi plagiarisme yang ada banyak sekali, bisa menggunakan alagoritma fuzzy, algoritma information retrieval, penggunaan metode Latent Semantic Analysis (LSA) untuk medeteksi kemiripan antar dokumen teks. LSA yaitu metode guna memaparkan hubungan dokumen dengan teks melewati term, antar dokumen teks bisa dilakukan penilaian kemiripannya dengan metode ini [2]. Tool genism dapat digunakan untuk deteksi dokumen-dokumen yang terdapat kemiripan. Gensim merupakan opensource digunakan secara khusus untuk teks-teks koleksi besar secara online menggunakan algoritma [3].

Penggunaan Vector space model untuk mendeteksi kemiripan sebuah dokumen. Deteksi kemiripan (plagiarism) di proses melalui beberapa tahapan yakni tokenisasi, stopword removal, stemming dan setelahnya di hitung bobotnya dan cosine similarity. Deteksi dan pemberian persentase kemiripan dokumen mahasiswa dapat dilakukan diaplikasi ini [4]. Salah satu teknik yang terbaru adalah pengembangan bahasa pemrograman Hypertext PreProcessor (PHP) dengan prosedur (kode program) yang dapat digunakan untuk mendeteksi kemiripan suatu teks.

Selain hal itu, proses pengelolaan skripsi di Prodi SI UMK juga masih dilakukan secara manual sehingga cukup sulit jika mahasiswa ingin mengecek judul skripsi yang akan diusulkan apakah ada kemiripan atau tidak dengan skripsi yang sudah pernah diusulkan oleh mahasiswa lain di Prodi SI UMK. Uraian permasalahan yang sudah dijelaskan, membuat peneliti mencari alternatif solusi untuk menyelesaikan permasalahan, dengan mengembangkan sebuah sistem informasi yang terintegrasi guna mengelola skripsi meliputi proses pendaftaran usulan skripsi, proposal skripsi dan proses sidang akhir serta memiliki fitur deteksi plagiarism dalam dokumen skripsi menggunakan prosedur PHP.

\section{KERANGKA PEMIKIRAN}

Tahapan-tahapan dalam rancang bangun system informasi manajemen skripsi dijelaskan dalam kerangka pemikiran. Permasalahan yang ada diselesaikan sesuai dengan proses yang sudah ditentukan untuk menghasilkan sistem dalam mencapai tujuan. Gambar 1 menjelaskan kerangka pemikiran sistem informasi manajemen skripsi.

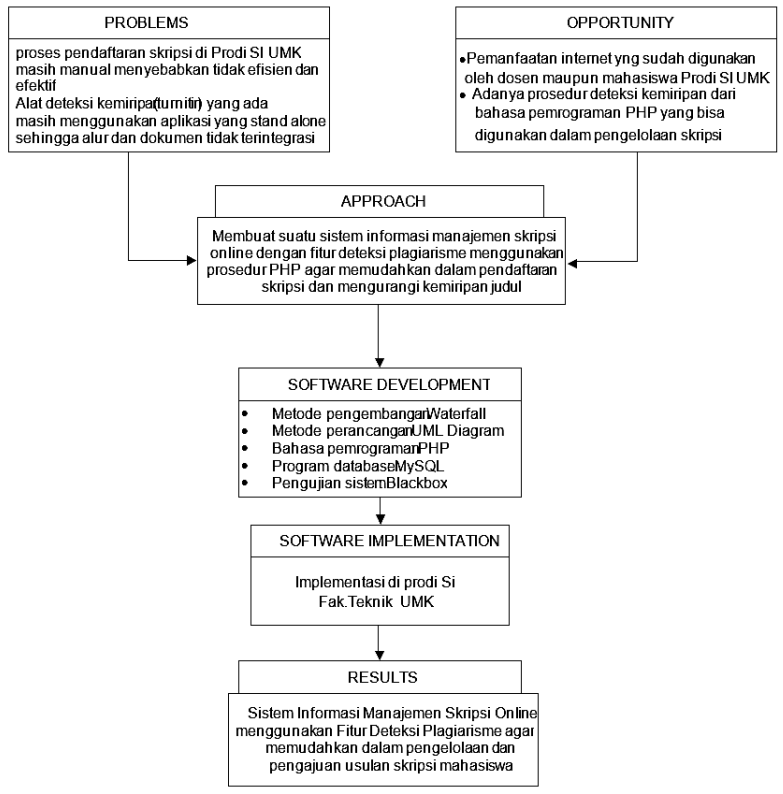

Gambar 1. Kerangka pemikiran Sistem Informasi Manajemen Skripsi 


\section{METODE PENELITIAN}

\subsection{Tahapan Penelitian}

Dalam penelitian ini terdapat tahapan-tahapan, yaitu :

a. Perencanaan Penelitian

Tahap pertama yaitu perencanaan penelitian, untuk perencaan penelitian dilaksanakan di Prodi Sistem Informasi Universitas Muria Kudus.

b. Pengumpulan Data

Pada tahap kedua, yaitu pengumpulan yang dilakukan dengan cara obervasi dan interview serta studi Pustaka dengan tujuan data yang didapatkan akurat dan sesuai.

1) Observasi

Observasi dilaksanakan dengan memngamati secara langsung proses pengelolaan data skripsi supaya tepat dalam mengetahui permasalahan secara detail yang harus diselesaikan.

2) Interview

Interview dilakukan dengan pihak-pihak yang memiliki kepentingan dan ada kaitannya dengan penelitian. Interview dilakukan secara langsung dengan tanya jawab dan secara tatap muka. Interview dilakukan peneliti dengan coordinator skripsi Prodi Sistem Informasi UMK.

3) Studi Pustaka

Pengumpulan data dengan cara ini dilakukan dengan mencari dan mengumpulkan teori-teori yang bisa dipakai untuk landasan teori seperti teori deteksi kemiripan dan teori pemrograman web PHP, jurnal-jurnal atau hasil penelitian mengenai kemiripan dokumen.

c. Metode pengembangan sistem.

Penelitian ini menggunakan metode pengembangan sistem waterfall yaitu model pengembangan yang paling banyak dipakai dan disebut pendekatan unggul di antara daur hidup pengembangan system lainnya [5].

Untuk tahapan-tahapan dalam model waterfall bisa di lihat di Gambar 2.

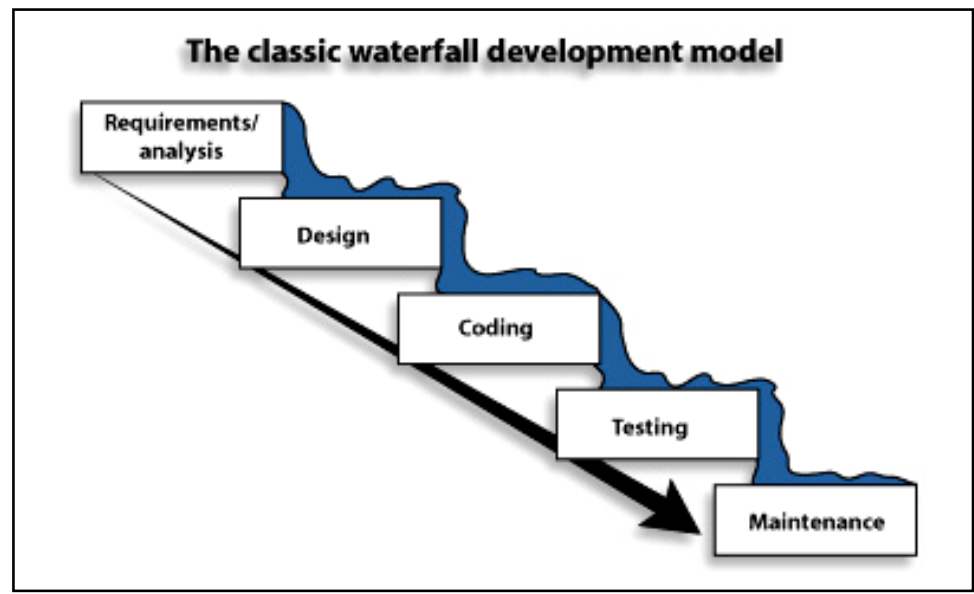

Gambar 2. Model Pengembangan Sistem Waterfall

\section{HASIL DAN PEMBAHASAN}

\subsection{Analisa dan Perancangan}

\subsubsection{Analisa Aktor}

Aktor dalam Sistem Informasi Manajemen Pendaftaran Skripsi Online dengan Fitur Deteksi Plagiarisme antara lain sebagai berikut:

1) Mahasiswa

Mahasiswa sebagai pembuat usulan skripsi dimana dapat mengecek kemiripan judul yang akan diusulkan dengan daftar judul yang sudah pernah ada di Prodi SI UMK serta dapat melakukan upload usulan secara online melalui sistem.

2) Bagian Administrasi

Bagian administrasi adalah koordinator skripsi yang ada di Prodi SI UMK yang dibantu oleh bagian operator. Tugas dari bagian administrasi adalah 
menerima usulan dari mahasiswa dengan mengecek persyaratan usulan serta mengelola pembagian dosen pembimbing serta dosen penguji untuk sidang akhir. Bagian administrasi juga dapat mengelola selesai atau tidaknya seorang mahasiswa dalam melaksanakan skripsi, apabila sudah melampaui batas akhir maka bagian administrasi dapat menjadikan status mahasiswa tersebut berakhir dan secara otomatis mahasiswa tersebut harus mengajukan usulan skripsi yang baru.

3) Dosen

Dosen bertugas untuk memberi persetujuan atas usulan skripsi yang diajukan mahasiswa. Sebelum melakukan persetujuan, dosen dapat mengecek kemiripan dari usulan dengan daftar skripsi yang sudah pernah ada di Prodi SI UMK.

4) Kaprodi

Kaprodi dapat memantau proses pengajuan usulan skripsi, daftar skripsi yang diterima maupun ditolak serta informasi terkait sidang skripsi mahasiswa.

\subsubsection{Arsitektur Sistem}

Adapun arsitektur dari Sistem Informasi Manajemen Pendaftaran Skripsi Online dengan Fitur Deteksi Plagiarisme yang dikembangkan dapat dilihat pada gambar 3 .

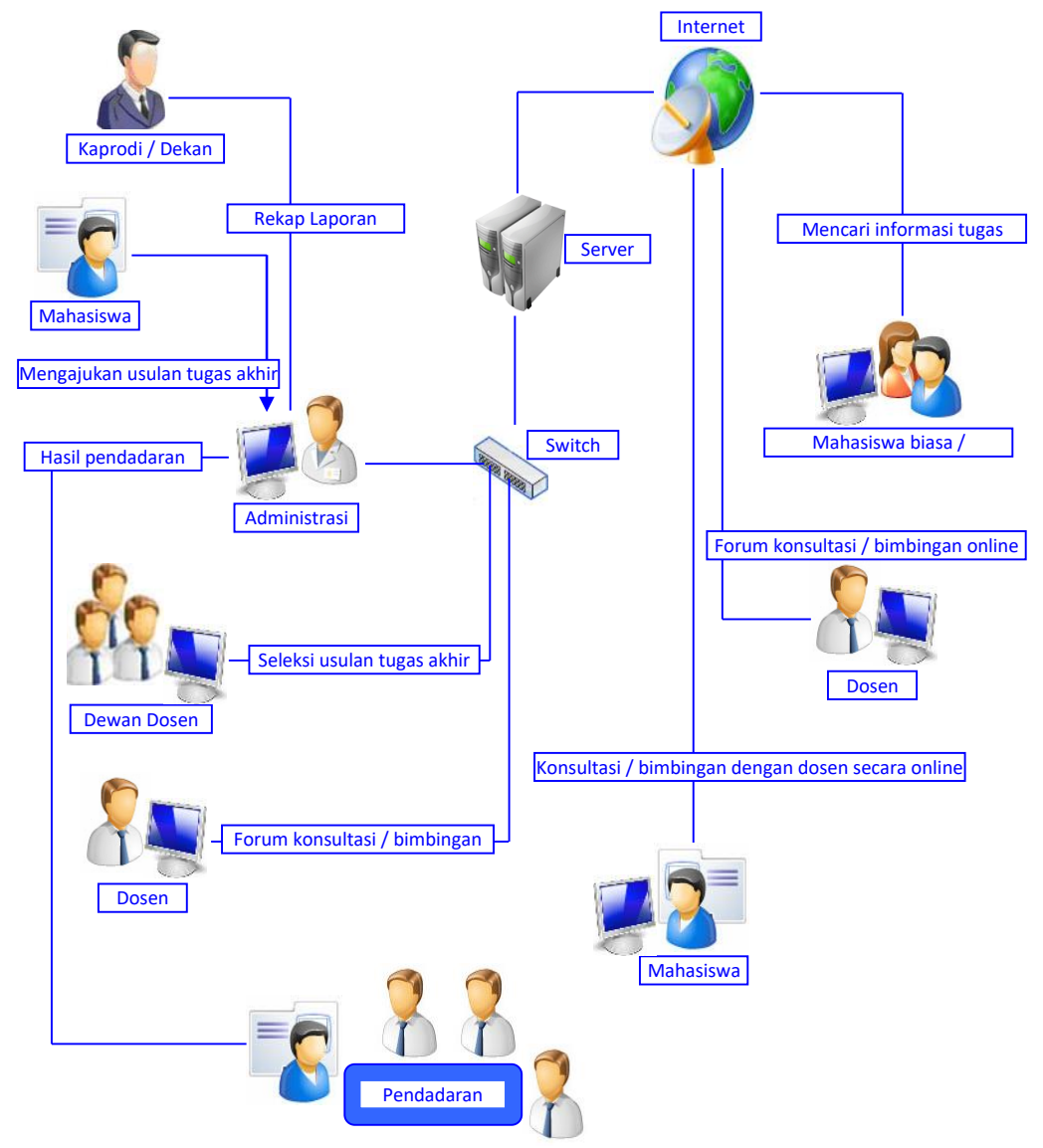

Gambar 3. Arsitektur dari Sistem Informasi Manajemen Pendaftaran Skripsi Online

\subsection{Use Case diagram Sistem Informasi Manajemen Pendaftaran Skripsi Online dengan Fitur Deteksi Plagiarisme}

Use case sistem dibuat guna menggambarkan proses sistem yang akan dibuat dengan jelas dan dapat dipahami. Dari tahapan proses bisnis diatas yang ada, maka terdapat 9 (sembilan) use case dan 4 (empat) aktor. Gambar 4 memberikan gambaran diagram use case sistem informasi manajemen pendaftaran skripsi oonline dengan fitur deteksi plagiarisme. 


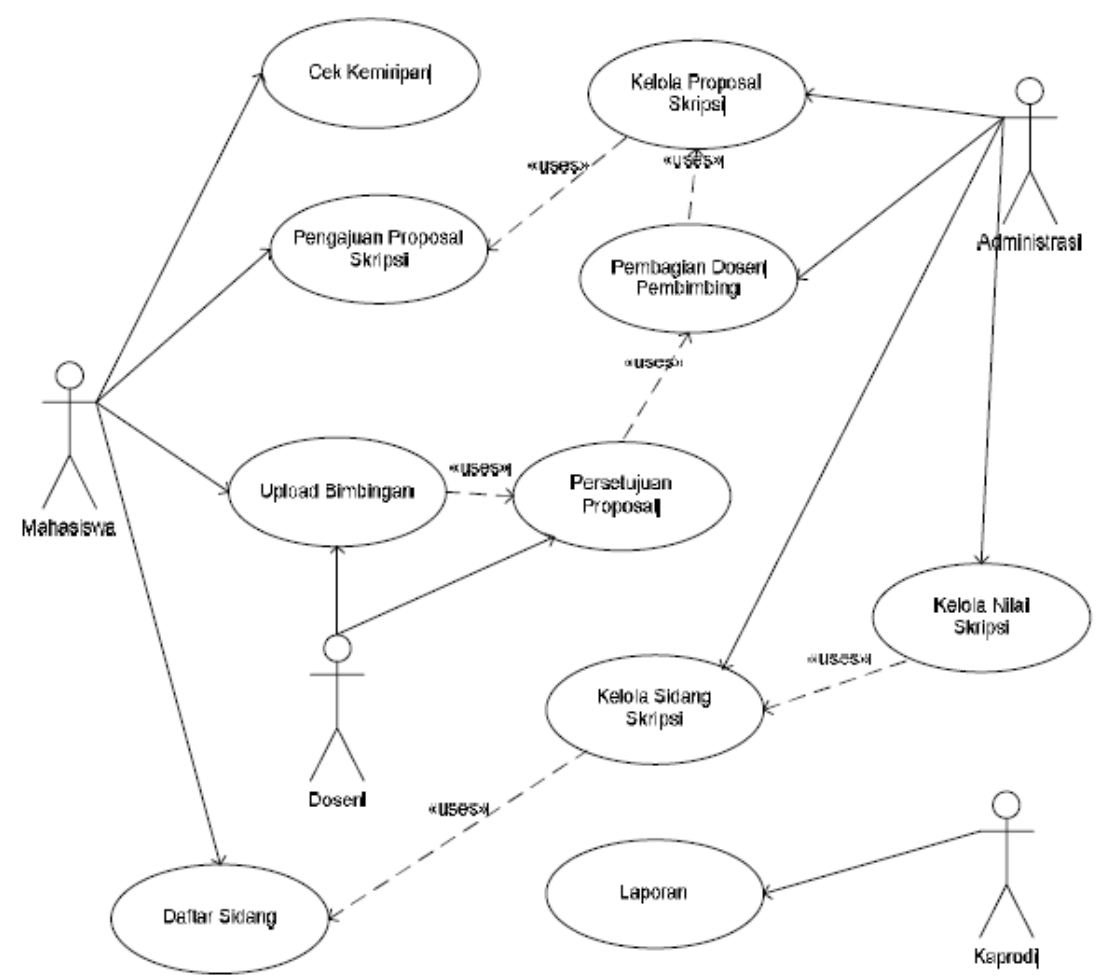

Gambar 4. Use Case Diagram Sistem Informasi Manajemen Pendaftaran Skripsi Online dengan Fitur Deteksi Plagiarisme

\subsection{Basis Data}

Data-data dari system informasi manajemen pendaftaran skripsi online diolah dengan MYSQL. Gambar 5 menunjukkan table-tabel dan relasi table dari Sistem Informasi Manajemen Pendaftaran Skripsi Online.

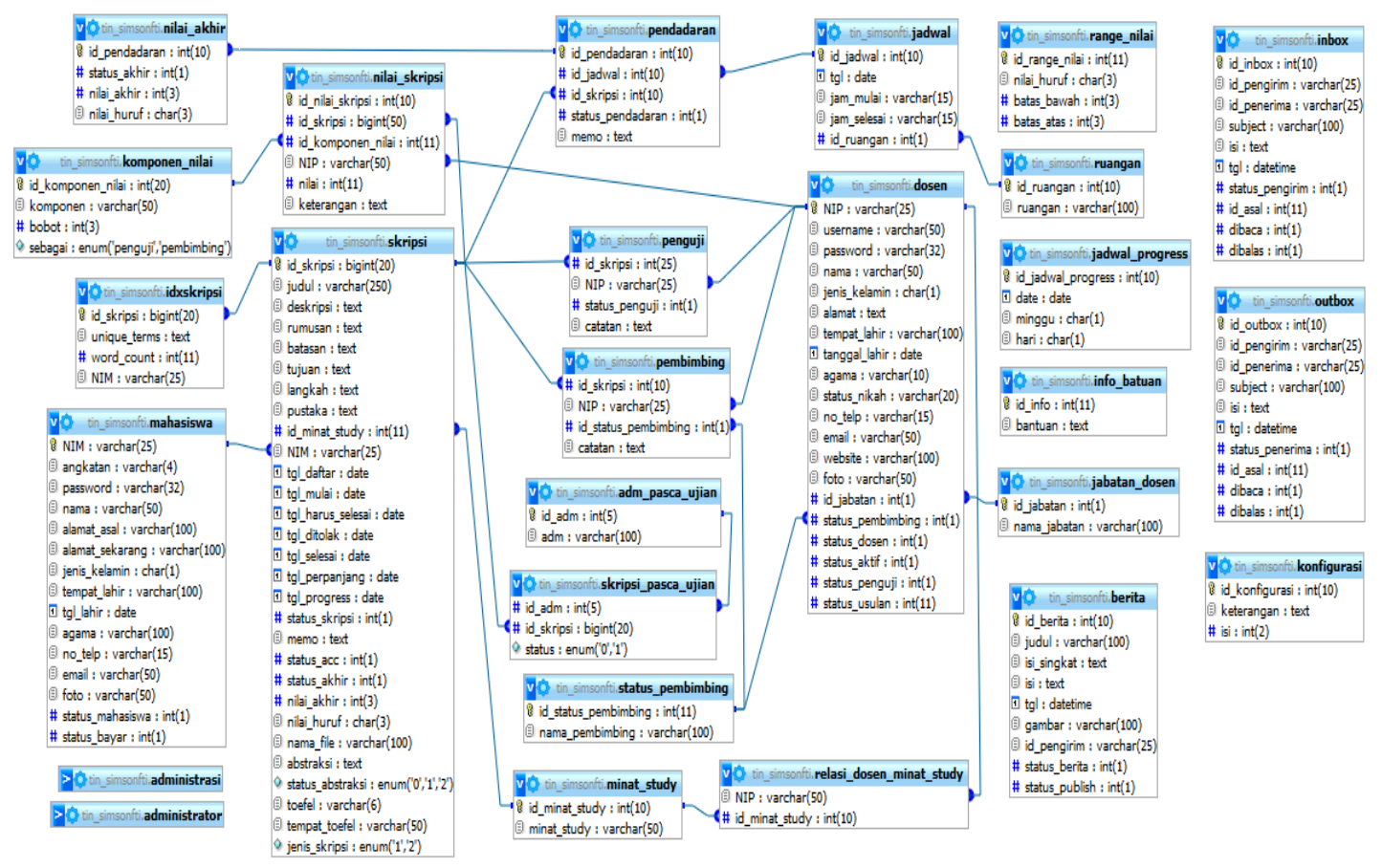

Gambar 5. Relasi Tabel Basis Data Sistem Informasi Manajemen Pendaftaran Skripsi Online 


\subsection{Implementasi}

a. Halaman menu utama

Halaman menu utama terdapat menu-menu yang bisa diakses tanpa login terlebih dahulu yaitu Cari Skripsi, Berita dan Pengumuman, dan Daftar Account. Gambar 6 merupakan tampilan halaman menu utama pada sistem informasi manajemen pendaftaran skripsi online.

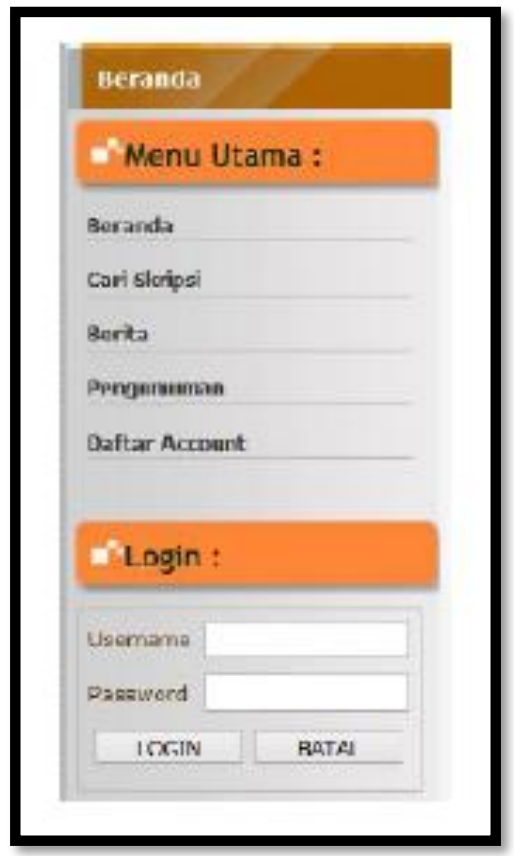

Gambar 6. Halaman Menu Utama

b. Antarmuka usulan skripsi

Antarmuka usulan skripsi digunakan untuk mengajukan proposal skripsi bagi mahasiswa yang belum mengajukan dan untuk melihat history bagi mahasiswa yang sudah mengajukan usulan skripsinya serta sekaligus melihat siapakah dosen pembimbingnya. Gambar 7 merupakan Tampilan usulan skripsi oleh mahasiswa.

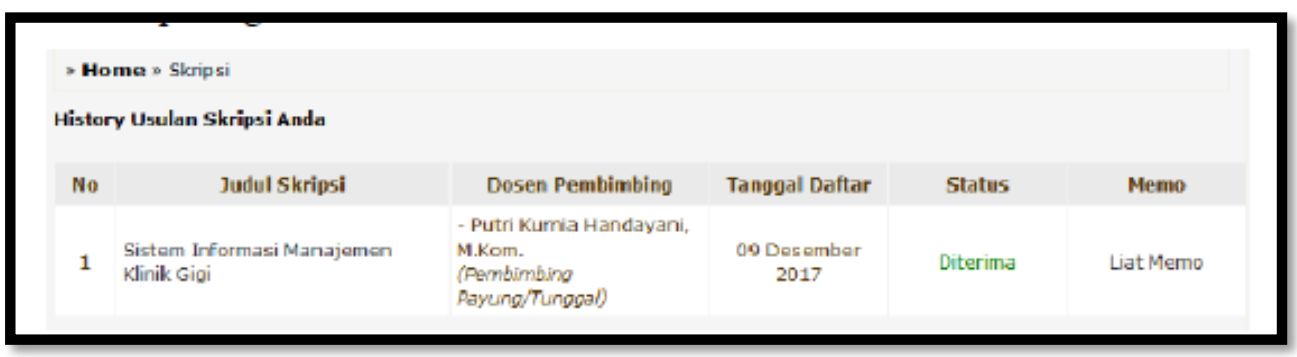

\section{Gambar 7. Tampilan Usulan Skripsi Mahasiswa}

c. Antarmuka menu manajemen skripsi

Antarmuka menu manajemen skripsi digunakan oleh bagian administrasi yang mengelola skripsi yang diusulkan dimana penentuan diterima atau tidaknya suatu usulan itu berdasarkan dari dosen pembimbing. Hasil dari penerimaan proposal dapat dilihat oleh bagian administrasi seperti pada Gambar 8 . 


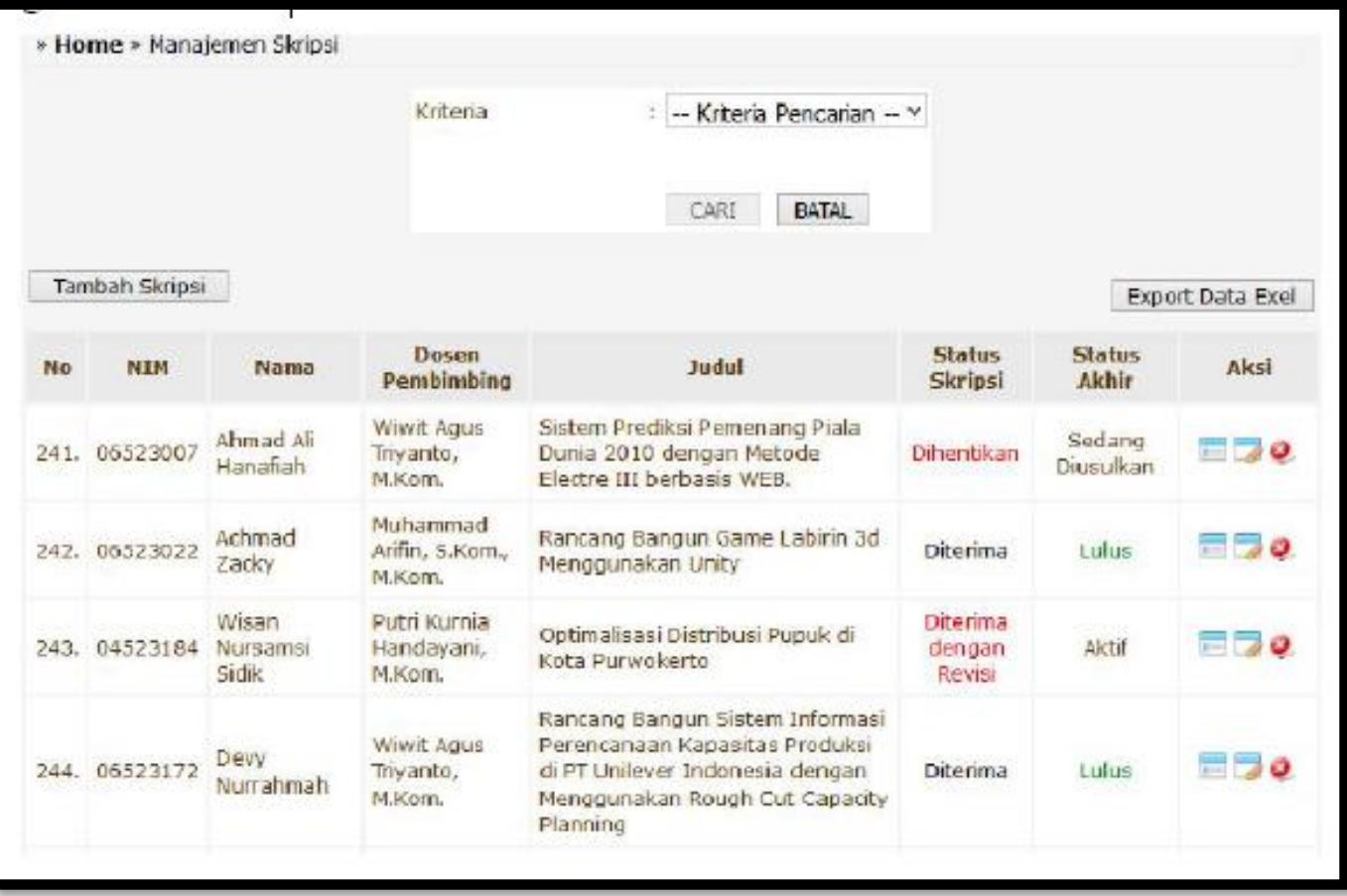

Gambar 8. Tampilan Manajemen Skripsi

\section{PENUTUP}

\subsection{Kesimpulan}

Setelah melalui beberapa tahapan penelitian diantaranya yaitu proses analisa, perancangan serta pembahasan, maka ada beberapa kesimpulan hasil yaitu :

1) Dihasilkan Sistem Informasi Manajemen Pendaftaran Skripsi Online untuk memudahkan proses pengajauan proposal skripsi dengan fitur deteksi kemiripan sehingga saat mahasiswa mengajukan usulan maka dapat dicek kemiripan dengan skripsi yang sudah pernah ada di Prodi Sistem Informasi Fakultas Teknik UMK.

2) Aplikasi yang dihasilkan membantu Koordinator Skripsi mengelola pendaftaran skripsi, pembagian dosen pembimbing serta dosen penguji.

3) Sistem ini juga memiliki fitur untuk penilaian hasil sidang skripsi, sehingga lebih mudah dapat mengelola nilai akhir skripsi.

\subsection{Saran-saran}

Hasil penelitian ini memerlukan saran-saran karena masih banyak perlu yang harus diperbaiki dan dikembangkan lagi dengan lebih baik. Berikut saran-saran penelitian :

1) Diharapkan sistem ini dapat lebih dikembangkan dalam bentuk yang lebih portable menggunakan aplikasi android maupun iOS sehingga memudahkan dalam pengelolaan dan pemantauan.

2) Diharapkan adanya integrasi dengan sistem yang sudah online di Universitas Muria Kudus sehingga sistem akan menjadi satu sistem terintegrasi.

\section{DAFTAR PUSTAKA}

[1] D. Mawarni, "Sistem Informasi VAlidasi Proposal Penelitian pada Program Studi Sistem Informasi Universitas Komputer Indonesia," Bandung, 2015.

[2] D. Wicaksono, M. Irawan and A. Rukmi, "Sistem Deteksi Kemiripan Antar Dokumen Teks Menggunakan Model BAyesian Pada Term Latent Semantic Analysi (LSA)," Jurnal Sains dan Seni POMITS , vol. 3, no. 2, 2014.

[3] K. Sekarwati, L. Banowosari, I. Wiryana and D. Kerami, "Pengukuran Kemiripan Dokumen Dengan Menggunakan Tools Gensim," in Prosiding Seminar Nasional Sains dan Teknologi (SNST) Fakultas Teknik Universitas Wahid Hasyim, Semarang, 2015.

[4] E. Oktalina, Tudesman, Tinaliah and Yoannita, "Sistem Deteksi Plagiarisme DOkumen Bahasa Indonesia menggunakan Metode Vector Space Model," Palembang, 2014. 
Jurnal SITECH, Vol 4, No 1, Juni 2021

P-ISSN : 2615-8531, E-ISSN : 2622-2973

[5] R. Pressman, Software Engineering :Practical Approach, Wembley-Hills, New York, 2002. 